\title{
Psychedelic drugs as a long-needed innovation in psychiatry
}

\author{
Genis Oña ${ }^{1}$, José Carlos Bouso ${ }^{1}$ \\ 1 International Center for Ethno botanical Education, Res earch, and Service (ICEERS)
}

\begin{abstract}
The field of psychiatry is facing unprecedented challenges. Despite recent important innovations, several mental disorders continue to lack effective treatment. After briefly exploring some of the current challenges, we suggest that the therapeutic use of psychedelic drugs in psychotherapeutic settings represents a promising and integ rative treatment with enduring effects for mental health patients. We then propose that psychedelic psychotherapy could be an important innovation in the field, providing a treatment that combines complex pharmacological action with enhanced psychotherapeutic interventions.
\end{abstract}

1. Introduction

Mental disorders, which remain among the most challenging health conditions in terms of treatment and recovery, are a major source of disability. Indeed, a recent study estimated that the global burden of mental disorders accounts for $32.4 \%$ of Years Lived with Disability (YLD) and 13\% of Disability-Adjusted Life-Years (DALYs) [1]. This distressing situation was arguably unexpected during the second half of the twentieth century, when the field of psychiatry enjoyed important advances. The use of electroconvulsive therapy, lobotomy, and insulin coma therapy during the 1930s and 1940s suggested that mental disorders could be cured through somatic therapies. This idea eventually materialized in the process that has been referred to as the "psychopharmacology revolution" [2], where the discovery of certain compounds (lithium, monoamine oxidase inhibitors, and phenothiazines) allowed for the symptoms of psychiatric disorders to be effectively reduced [3]. In this manner, the field of psychiatry developed new patterns of assistance, reducing the number of patients admitted to institutions, and therefore improving their quality of life.

The efficacy encountered through the use of psychopharmacological tools, along with 
the bacteriological model adopted in other medical areas, led to the development of the "chemical imbalance" theory regarding mental disorders. This theory proposed that mental disorders are caused by imbalances in certain chemical compounds in the brain, imbalances that could potentially be regulated using psychiatric medications [4]. All of these achievements became foundational to what is today called the "biomedical model," an evidence-based paradigm that assumes that most mental disorders are biologybased brain diseases. Unfortunately, improvements in mental healthcare outcomes under the biomedical model have stalled during recent decades [5-8], while criticisms of the biomedical model have emerged $[9,10]$.

Proponents of the biomedical model have faced hostile critiques from Freudian practitioners and advocates of the "anti-psychiatry" movement, but recently even the Special Rapporteur of the United Nations called for the adoption of a human rights-based approach as an alternative to the biomedical model: "Current mental health policies have been affected to a large extent by the asymmetry of power and biases because of the dominance of the biomedical model and biomedical interventions. This model has led not only to the overuse of coercion in case of psychosocial, intellectual and cognitive disabilities, but also to the medicalization of normal reactions to life's many pressures, including moderate forms of social anxiety, sadness, shyness, truancy and antisocial behavior" [11]. We must therefore seek to offer an honest, careful, and objective overview of the situation, starting with a brief description of what we consider to be the most relevant challenges that the field of psychiatry faces. Considering that knowledge, we then suggest how the therapeutic use of psychedelic drugs may improve the current scenario significantly.

\section{Challenges of the biomedical model in psychiatry}

Unfounded hypotheses

The publication of DSM-III was a major achievement in the history of psychiatry, since it marked the first time that mental disorders were classified in discrete categories constructed from observable symptoms that were consensus-based. The scientific background of the field began with the above-mentioned "psychopharmacology revolution" that was completely fulfilled with the DSM-III, increasing the proximity between psychiatry and medicine [12]. 
This classification of mental disorders suggested that, for each one of them, specific and differential biological causes could be found and subsequently treated using highly selective psychiatric drugs. Nonetheless, up until the present, no single biomarker has been found for any psychiatric disorder [13]. Additionally, in the field of pharmacology it has been observed that focusing on certain molecular targets is a limited approach, especially in the case of complex disorders, such as psychiatric ones [14,15]. For instance, most antipsychotic drugs have a multi-target profile, binding to more than twenty targets. These multi-target effects are being increasingly valued, since the potential biological causes of mental disorders are being reinterpreted as complex networks instead of isolated targets, and fields such as network pharmacology and systems biology are providing new understandings [16]. However, the causality underlying mental disorders cannot be attributed to those biological systems modulated by multi-target drugs. This was the procedure when suggesting the monoaminergic hypothesis of depression: after observing the effects of drugs with certain binding affinities, etiological hypotheses were proposed [3]. But this is a kind of non causa pro causa fallacy, in which a cause of a phenomenon is incorrectly identified. Knowing the effect of drugs on psychiatric symptoms does not provide information regarding the pathophysiology of mental disorders. Therefore, at this point we should admit that the etiological hypotheses regarding mental disorders remain unsupported.

Failure in diagnosis

It is precisely due to the lack of supporting evidence for the etiological hypotheses regarding mental disorders that their diagnosis is more complex than it should be. Without specific biological causes and tests to verify them, the diagnostic process commonly relies upon the subjective assessment of clinicians [17]. Furthermore, recent research [18] suggests that the classification of disorders in discrete categories with differential symptoms should be abandoned, since specific single-nucleotide polymorphisms (SNPs) are actually associated with a wide range of psychiatric disorders. The same conclusions were reached in a recent study from a clinical perspective [19]. The authors found that for a large proportion of symptoms there was overlap between distinct diagnostic categories, so they suggested enhancing the consideration of individual experiences and the underestimated role of trauma in various mental disorders. 
The widespread use of psychopharmacological tools from the 1980s could have ideally translated to a decrease in the prevalence, severity, and chronicity of certain psychiatric disorders. However, a study that assessed relevant indicators in Australia, Canada, England, and United States between 1990 and 2015 found that the prevalence of such disorders increased, although treatments were highly available [20]. Another study [21] found that long-term outcomes regarding mood disorders, at a time when no medications were used (before the 1970s), were generally positive: nearly $70 \%$ of patients recovered over various periods of times that were generally longer than 10 months. In the "treatment era," antidepressant treatment reduced the length of mood episodes, but increased their recurrence. Similarly, Patten [22] found that increased use of antidepressant drugs was associated with an increased prevalence and duration of depressive episodes. The largest clinical trials to assess the long-term efficacy of treatments for depression and bipolar disorder (STAR*D and STEP-BD, respectively) had shown poor results. In the first case, most patients did not experience long-term remission even when changing between medications up to three times after no response was reported [8]. In the second case, only $23 \%$ of patients with bipolar disorder remained well after receiving treatment according to best-practice psychiatric guidelines [23]. Thus, it seems that certain mental disorders are becoming chronic and treatment-resistant conditions [5]. Some authors have suggested that the long-term use of these drugs may paradoxically worsen outcomes related to the disorders that they are intended to treat [6].

Post-traumatic stress disorder (PTSD) is another example of an inappropriately treated condition, as the PTSD Psychopharmacology Working Group of the US Department of Veteran Affairs recently stated [24]. There are only two medications approved for the treatment of PTSD, sertraline and paroxetine, which only offer a reduction in symptom severity rather than PTSD remission [24]. Since 2001, no new medications have been approved for the treatment of PTSD, despite the significant need. This scenario has pushed clinicians to adopt poly-pharmacy approaches for the vast majority of their patients, using off-label medications regarding which there is little empirical guidance concerning risks or benefits [24]. Among these medications, we find benzodiazepines, which are not only ineffective but are also associated with negative psychotherapy outcomes, aggression, depression, and illicit substance use among PTSD patients [25]. Moreover, long-term treatment with these medications might be more harmful than beneficial $[26,27]$. 
Not an affordable model

In 2018, the Nesta foundation published the report "T he Biomedical Bubble" [28]. The authors claimed that the Life Sciences in the UK were in a precarious situation due to their immersion in the "biomedical bubble." According to the authors, biomedicine has provided a remarkable body of knowledge that has helped lower mortality rates and improved health outcomes. However, during recent years, the sector has suffered a crisis in Research \& Development (R\&D) productivity (the R\&D returns for twelve of the top global research-based life science companies declined to 3.2\% in 2017, down from 10.1\% in 2010) and it has become increasingly difficult to believe in the continued success of the pharmaceutical industry [29]. For that reason, the authors of the report suggest that more should be invested into research regarding the social, environmental, digital, and behavioral determinants of health. Additionally, other recent debates have taken place regarding the public returns resulting from investments in biomedicine and claiming for the universal access to medicines, due to the high costs of new drugs [30-33].

3. Recent innovations that worked

As can be clearly seen, psychiatry urgently needs innovative and effective treatments for mental disorders. Although they are few, we have witnessed the development of some treatments in recent years [34]. One clear example is ketamine, a rapid-acting antidepressant with sustained effects that is currently approved (specifically as Senantiomer, esketamine, under the brand name Spravato (C) by the Food and Drug Administration (FDA) for treatment-resistant depression. Some authors suggest that the clinical use of ketamine is the greatest breakthrough in the field of depression treatment in over sixty years [35]. Another example is brexanolone (Zulresso (c)), which has also shown rapid and durable antidepressant effects, and it has become the first drug to be specifically approved for postpartum depression. Cannabidiol, or CBD, is a promising cannabinoid used for the treatment of schizophrenia [36]. Indeed, it could be the first antipsychotic drug interacting with both the CB1 receptor (as a negative allosteric modulator) and the D2 receptor (as a partial agonist).

4. Psychedelic drugs as innovative treatments 
Beyond ketamine and cannabinoids, there are also other psychedelic drugs that could offer a partial solution in response to the current needs of psychiatry [37,38]. Classic treatment targ ets for disorders like depression and PTSD have been too focused on symptom relief instead of recovery $[39,40]$. Psychiatric disorders are complex phenomena, and instead of an oversimplified approach, psychedelic drugs offer the more integ rative treatment that is arguably required in such cases. They combine pharmacological tools, enhanced psychotherapeutic interventions, and also therapeutically-meaningful subjective experiences [37].

Many psychedelic drugs were extensively investigated in the 1950s and 1960s, being administered to more than 40,000 individuals for various purposes. The results obtained suggested the efficacy of lysergic acid diethylamide (LSD) and other psychedelic drugs for the treatment of anxiety, depression, and substance use disorders [41,42]. However, the regulatory environment changed rapidly once these substances began to be used by the general population. In the War on Drugs context, LSD and similar substances were outlawed by the Controlled Substances Act in the US, and by the United Nations Convention on Psychotropic Substances. After several decades, some studies involving psychedelic drugs were reinitiated in the 1990s, due to a renewed interest in their therapeutic potential, and this has continued to a greater extent since the early 2000s. Modern techniques and robust methodologies used in recent studies have provided extensive knowledge regarding neurobiological mechanisms [39] and the relevance of psychological effects [43].

Neurobiological mechanisms of psychedelic drugs

Psychedelic drugs activate different G-protein-coupled receptors (GPCRs), but several studies have identified 5-HT2A as the main receptor responsible for the behavioral effects of psychedelic drugs [39]. However, their therapeutic effects are much more complexity, as the correlations between psychiatric disorders and specific 5-HT2A receptor/neurotransmitter systems generally fail as possible explanations [44]. Other closely related serotonin receptors could also be involved, such as 5-HT1A and 5-HT2C [45]. Beyond serotonin receptors, N,N-Dimethyltryptamine (DMT) and LSD also activate trace amine-associated receptors (TAAR1) [46], the agonism of which is associated with antipsychotic, antidepressant, and anti-addictive properties [46]. Particular binding profiles will be found for different substances. For instance, DMT also has an agonist effect on the sigma-1 receptor, which is involved in several conditions, such as addiction, 
depression, amnesia, cancer, and pain [47]. Salvinorin-A, a non-nitrogenous diterpene, exerts its potent psychedelic effects through a highly selective agonism on the kappaopioid receptor instead of 5-HT2A [48].

A relevant effect of most psychedelic drugs is their recently discovered enhancement of neurogenesis and neural plasticity. The activation of 5-HT2A receptors has been associated with neurogenesis [49,50], and neuronal plasticity [51]. Remarkably, DMT and other psychedelics have been termed "psychoplastogens" due to their promotion of rapid structural and functional neural plasticity [52]. This emphasis on the modulation of neural circuits through fast-acting psychoplastogens, instead of rectifying chemical imbalances using long-term treatments, suggests a considerable paradigm shift and fertile ground for further research not only regarding psychiatric disorders but also neurodegenerative conditions.

Psychedelic drugs have also been recently discovered to have anti-inflammatory effects. This could have implications not only for psychiatric disorders in which inflammation is an essential component, but also for various physical conditions and neurodeg enerative disorders [45]. Although serotonin acting via 5-HT2 receptors produces proinflammatory actions [53] psychedelic drugs such as LSD and 2,5-Dimethoxy-4iodoamphetamine (DOI) primarily show potent anti-inflammatory effects [54]. In the case of DOI, it seems to be an extraordinarily potent anti-inflammatory agent, since it has an EC50 of 15 picomolar in preventing Tumor Necrosis Factor alpha (TNF- $\alpha$ ) mediated inflammation in aortic smooth muscle cells [54]. Interestingly, the therapeutic dose is much lower than the dose capable of producing behavioral effects.

The effects of psychedelic drugs could also be explained in terms of alterations to functional connectivity in brain networks. A disintegration of the Default Mode Network (DMN) has been observed after administering either psilocybin [55], LSD [56], or ayahuasca [57]. In the case of psilocybin, it also caused decreased activity and connectivity in the medial prefrontal cortex (MPFC). This is especially relevant since this region shows enhanced activity in depressed patients [58], which is attenuated after depression treatment [59]. It has been suggested that psychedelic drugs can weaken well-established brain networks and at the same time reduce the degree of segregation between them. Due to this general effect, the normal organization of brain networks is disrupted, and thereafter strong, topologically long-range functional connections not previously present can emerge, and brain networks are reconnected in a "healthier" way $[44,60]$. 
The neuroendocrine effects of psychedelic drugs have also been suggested by some authors as being potentially implicated in their therapeutic effects [61]. For instance, psychedelic drugs generally increase the concentrations of oxytocin, which can have implications for psychotherapy, since the administration of oxytocin to patients leads to changes in individual and dynamic factors in patients with depression and PTSD [62].

Our group has also published an article that suggests there is a need to study the therapeutic effects of psychedelic drugs from the polypharmacology perspective (Ona \& Bouso, 2019). Indeed, most psychedelic drugs currently used in clinical settings are derived from natural sources (psilocybin, DMT), so they have a multi-target profile that should not be ignored when attempting to elucidate their mechanisms of action.

Psychological effects

In therapeutic settings, the drug (generally psilocybin, LSD, or ayahuasca) is used on one or a few occasions during psychotherapy sessions, helping an individual to overcome obstacles and to catalyze the therapeutic experience [37]. In this manner, psychedelic drugs can trigger meaning ful personal experiences $[64,65]$, facilitate introspective insights [37] and enhance the relationship between the therapist and the patient [66].

The psychedelic experience itself offers important therapeutic effects [43]. Indeed, the best outcomes in the clinical trials where psychedelic drugs were administered were obtained in those patients reporting intense mystical-type or peak experiences [67-69]. Interestingly, it would not always be necessary to achieve these powerful experiences in order to obtain useful personal and interpersonal insights, since it has been observed that emotional breakthroughs that commonly occur in psychedelic therapy are essential to the process as well [70].

The experiences induced by psychedelic drugs in therapeutic contexts seem to change an individual's personality structure into a healthier one [71], and these changes have been related to pro-environmental behaviors [72] and lower levels of intimate partner violence [73]. Thus, beyond individual benefits, we can also expect associated social and community benefits as a result of psychedelic-assisted psychotherapy. 


\section{Contemporary studies}

Several clinical trials using psychedelic drugs or 3,4-Methylenedioxymethamphetamine (MDMA) have recently been published and show promising results for the treatment of depression [56,74-76], anxiety in cancer patients [77-80], addictions [81], social anxiety in autism [82], and PTSD [83-87]. See Table 1 for more details. Indeed, beyond the mere demonstration of efficacy, it has been suggested that some of these treatments could represent the first evidence-based and pharmacologically-mediated cures for mental disorders to be found in psychiatry [88]. In addition to these substances, the therapeutic potential of ibogaine for the treatment of addictions is also remarkable, mostly in terms of the treatment of opioid dependence [89], as it offers a potential solution to the opioid crisis occurring in many countries. Two randomized controlled trials in which ibogaine will be administered to patients with alcoholism and patients included in Methadone Maintenance Programs will beg in this year (ClinicalT rials.gov Identifiers: NCT 03380728 and NCT 04003948, respectively). 


\begin{tabular}{|c|c|c|c|c|}
\hline RCT & Core topic & $\begin{array}{l}\mathrm{N}^{\circ} \text { of } \\
\text { patients }\end{array}$ & Main findings & Limitations \\
\hline $\begin{array}{l}\text { Grob et } \\
\text { al. } 2011\end{array}$ & $\begin{array}{l}\text { Psilocybin for the } \\
\text { treatment of anxiety } \\
\text { associated with life- } \\
\text { threatening } \\
\text { disease }\end{array}$ & 12 & Significant reductions in anxiety & $\begin{array}{l}\text { No control } \\
\text { group }\end{array}$ \\
\hline $\begin{array}{l}\text { Mithoefer } \\
\text { et al. } \\
2011\end{array}$ & $\begin{array}{l}\text { MDMA for the } \\
\text { treatment of PTSD }\end{array}$ & 20 & $\begin{array}{l}\text { MDMA-assisted psychotherapy can } \\
\text { be safely administered to PTSD } \\
\text { patients, and it may be useful in } \\
\text { patients refractory to other } \\
\text { treatments }\end{array}$ & $\begin{array}{l}\text { Potential } \\
\text { selection bias }\end{array}$ \\
\hline $\begin{array}{l}\text { Oehen et } \\
\text { al. } 2013\end{array}$ & $\begin{array}{l}\text { MDMA for the } \\
\text { treatment of PTSD }\end{array}$ & 12 & $\begin{array}{l}\text { MDMA-assisted psychotherapy can } \\
\text { be safely administered in a clinical } \\
\text { setting }\end{array}$ & $\begin{array}{l}\text { Low adherence } \\
\text { to MDMA- } \\
\text { psychotherapy } \\
\text { protocol }\end{array}$ \\
\hline $\begin{array}{l}\text { Gasser } \\
\text { etal. } \\
2014\end{array}$ & $\begin{array}{l}\text { LSD for the } \\
\text { treatment of anxiety } \\
\text { associated with life- } \\
\text { threatening }\end{array}$ & 12 & $\begin{array}{l}\text { When administered safely in a } \\
\text { medically supervised } \\
\text { psychotherapeutic setting, LSD can } \\
\text { rediıre anxiatı }\end{array}$ & $\begin{array}{l}\text { Potential } \\
\text { selection bias }\end{array}$ \\
\hline
\end{tabular}

Table 1. Modern Randomized Clinical Trials (RCT) involving the administration of psychedelic substances. $\mathrm{RCT}=$ Randomized Clinical Trial; MDMA=3,4-Methylenedioxymethamphetamine; PTSD= Posttraumatic Stress Disorder; LSD= Lysergic acid diethylamide; AEs= Adverse Events.

The Journal of Psychopharmacology, Psychopharmacology, Neuropharmacology, and the Journal of Psychoactive Drugs dedicated entire issues to psychedelic drugs, in December of 2016, February of 2018, November of 2018, and May of 2019, respectively. The United States' FDA has designated MDMA and psilocybin-assisted psychotherapies as "breakthrough therapies," and Phase-III and Phase-II clinical trials are in development for these drugs, respectively. Thus, it is quite probable that psychedelic-assisted psychotherapy will be approved for the treatment of certain disorders in the next few 
years.

\section{Combining biomedical knowledge with traditional practices}

Psychedelic plants have been traditionally used in many cultures, and some authors have stated that they should be framed within pluralistic medical systems [90]. The use of these plants by traditional healers and religious communities can provide us with privileged knowledge regarding how to better use them in our culture. In traditional systems, psychoactive plant rituals are performed with the participation of a whole community, with the goal of enhancing social connection [91,92]. In this manner, the "treatment" goes far beyond the ritual itself, constituting a long and complex process. In the case of modern psychedelic psychotherapy, maybe we would have to look for a treatment that goes far beyond the "administration" of drugs as well.

The central role of community in the process of healing has been systematically neglected in Western psychiatry, which has adopted an individualistic approach to mental health. In this regard, it has been observed that community-based interventions can have a more positive psychological impact than individualistic approaches [93-95]. Thus, it could be a good idea to consider expanding the complexity of psychedelic psychotherapies further, where a (poly)pharmacological action and psychological effects enhancing therapeutic interventions are combined with strategies that promote social connection. A good option may be the administration of psychedelic drugs to groups instead of individual sessions, as some authors have been testing [96].

This approach is sensible considering that social isolation and loneliness are now considered major public health concerns, with some studies concluding that extreme loneliness predicts greater severity of symptoms, a slower recovery, and worse treatment outcomes in people affected by depression, bipolar disorder, and anxiety [97], increasing the risk of premature death by more than 20\% [98]. Additionally, the greater focus on social support and social bonds is in accordance with suggestions recently published by the Special Rapporteur of United Nations, in support of the replacement of the biomedical model with a human rights-based approach, as previously mentioned [11].

7. Undesired effects of psychedelic drugs 
We should remember that there is a growing tendency towards the ritualistic and communal use of plants like ayahuasca [99]. In contrast with clinical trials, the notion that psychedelic drugs are harmful is challenged when we examine real-world situations. Psychedelic drug use is associated with a lower rate of mental health problems [100] and with reduced psychological distress and suicidality [101] in population studies. Preliminary evidence from a public health perspective [102] showed that the long-term ritualistic use of psychedelic drugs was associated with a higher positive perception of health and a healthy lifestyle. Additionally, 56\% of the sample reduced their use of prescription drugs due to their use of ayahuasca.

Despite the apparent safety and associated advantages, we must not forget the limitations of psychedelic-assisted psychotherapy. Current evidence is limited, so more studies are needed in order to better describe potentially serious adverse events and the effectiveness of treatments. Additionally, not all patients would be candidates. For instance, psychedelic-assisted psychotherapy should not be used to treat patients with a personal or family history of nonpsychotic mania or a psychotic disorder, since psychotic episodes can occur due to the use of psychedelic drugs [103]. Additionally, some published cases have shown that subjects without previous symptoms also developed psychopathological crises [103]. For this reason, patients who are administered psychedelic drugs should be properly screened using strict inclusion / exclusion criteria [104].

\section{Conclusion}

The need for innovative treatments in psychiatry could be responded to in part through the greater introduction of psychedelic psychotherapies. They represent an integrative approach to mental health, involving the use of pharmacological tools that can be combined with enhanced psychotherapeutic interventions and, as we propose, community-based interventions. Furthermore, in contrast to the majority of psychiatric medications, only a few administrations would be necessary, so this could mean important savings for public health systems in terms of both direct and indirect costs. This is highly relevant considering the claims made by Nesta and other organizations regarding poor outcomes related to biomedicine investment. However, we should remember that psychedelic psychotherapy is far from being a panacea. Potential risks exist, and patients with psychotic or bipolar disorders will have to continue seeking out other kinds of treatments. Nonetheless, psychedelic drugs represent an exciting and 
long-needed innovation in the field of psychiatry.

Author contributions

G.O. and J.C.B. contributed equally to this work.

Funding sources

This research did not receive any specific grant from funding agencies in the public, commercial, or not-for-profit sectors.

\section{References}

[1] Vigo, D.; Thornicroft, G.; Atun, R. Estimating the true global burden of mental illness. Lancet Psychiatry, 2016, 3(2), 171-178.

[2] Green, A.R.; Haddad, P.M. The British Association for Psychopharmacology: The first forty years. British Association for Psychopharmacology: Cambridge, 2016.

[3] Deacon, B.J. The biomedical model of mental disorder: A critical analysis of its validity, utility, and effects on psychotherapy research. Clin. Psychol. Rev., 2013, 33(7), 846-861.

[4] Insel, T .R. Disruptive insights in psychiatry: transforming a clinical discipline. J. Clin. Invest., 2009, 119(4), 700-705.

[5] El-Mallakh, R.S.; Gao, Y.; Roberts, R.J. Tardive dysphoria: The role of long term antidepressant use in inducing chronic depression. Med. Hypotheses, 2011, 76, 769-773. [6] Fava, G.A.; Offidani, E. The mechanisms of tolerance in antidepressant action. Prog. Neuropsychopharmacol. Biol. Psychiatry, 2010, 15, 1593-1602.

[7] Hengartner, M.P.; Plöderl, M. Statistically significant antidepressant-placebo differences on subjective symptom-rating scales do not prove that the drugs work: Effect size and method bias matter! Front. Psychiatry, 2018, 9, 517.

[8] Rush, A.J.; Madhukar, H.; Trivedi, S.R.; Wisniewski, S.R.; Nierenberg, A.A.; Stewart, J.W.; Warden, D.; Niederehe, G.; Thase, M.E.; Lavori, P.W.; Lebowitz, B.D.; McGrath, P.J.; 
Rosenbaum, J.F.; Sackheim, H.A.; Kupfer, D.J.; Luther, J.; Fava, M. Acute and longer-term outcomes in depressed outpatients requiring one or several treatment steps: A STAR*D report. Am. J. Psychiatry, 2006, 163(11), 1905-1917.

[9] Horrobin, D.F. Scientific medicine-success or failure? In: Oxford Textbook of Medicine; D.J. Weatherall, J.G.G. Ledingham, \& D.A. Warrell, Eds.; Oxford University Press: Oxford, 1987; 2nd Ed. p. 2.1-2.3.

[10] Lacasse, J., \& Leo, J. Serotonin and depression: A disconnect between the advertisements and the scientific literature. PLoS Med., 2005, 2, 1211-1216.

[11] Pūras, D. Right of everyone to the enjoyment of the highest attainable standard of physical and mental health. Forty-first session, Human Rights Council, General Assembly, UN. 2019. Retrieved from: https://www.un.org/en/ga/search/view_doc.asp? symbol=A/HRC/41/34

[12] Shorter, E. The history of nosology and the rise of the Diagnostic and Statistical Manual of Mental Disorders. Dialogues Clin. Neurosci., 2015, 17(1), 59-67.

[13] Rose, N. Neuroscience and the future for mental health? Epidemiol. Psychiatr. Sci., 2016, 25(2), 95-100.

[14] Peters, J.U. Polypharmacology - foe or friend? J. Med. Chem., 2013, 56(22), 89558971.

[15] Roth, B.L.; Sheffler, D.J.; Kroeze, W.K. Magic shotguns versus magic bullets: selectively non-selective drugs for mood disorders and schizophrenia. Nat. Rev. Drug Discov., 2004, 3(4), 353-359.

[16] Wong, E.H.F.; Tarazi, F.I.; Shahid, M. The effectiveness of multi-target agents in schizophrenia and mood disorders: Relevance of receptor signature to clinical action. Pharmacol. Therap., 2010, 126(2), 173-185.

[17] Timimi, S. No more psychiatric labels: Why formal psychiatric diagnostic systems should be abolished. Int. J. Clin. Health Psychology, 2014, 14(3), 208-215.

[18] Cross-Disorder Group of the Psychiatric Genomics Consortium. Identification of risk loci with shared effects on five major psychiatric disorders: a genome-wide analysis. Lancet, 2013, 381(9875), 1371-1379.

[19] Allsopp, K.; Read, J.; Corcoran, R.; Kinderman, P. Heterogeneity in psychiatric diagnostic classification. Psychiatry Res., 2019. Doi: 10.1016/j.psychres.2019.07.005. [20] Jorm, A.F.; Patten, S.B.; Brugha, T.S.; Mojtabai, R. Has increased provision of treatment reduced the prevalence of common mental disorders? Review of the evidence from four countries. World Psychiatry, 2017, 16(1), 90-99.

[21] Mulder, R.T .; Frampton, C.M. Outcome of mood disorders before psychopharmacology: a systematic review. Aust. N. Z. J. Psychiatry, 2014, 48(3), 224236. 
[22] Patten, S.B. The impact of antidepressant treatment on population health: synthesis of data from two national data sources in Canada. Popul. Health Metr., 2004, 2(1), 9.

[23] Schneck, C.D.; Miklowitz, D.J.; Miyahara, S.; Araga, M.; Wisniewski, S.; Gyulai, L.; Allen, M.H.; Thase, M.E.; Sachs, G.S. The prospective course of rapid-cycling bipolar disorder: Findings from the STEP-BD. Am. J. Psychiatry, 2008, 165(3), 370-377.

[24] Krystal, J.H.; Davis, L.L.; Neylan, T.C.; Raskind, M.; Schnurr, P.P. It is time to address the crisis in the pharmacotherapy of posttraumatic stress disorder: A consensus statement of the PT SD Psychopharmacology Working Group. Biol. Psychiatry, 2017, 82, e51-e59.

[25] Guina, J.; Rossetter, S.R.; DeRhodes, B.J.; Nahhas, R.W.; Welton, R.S. Benzodiazepines for PTSD: A Systematic Review and Meta-Analysis. J. Psychiatr. Pract., 2015, 21(4), 281 303.

[26] de Gage, S.B.; Moride, Y.; Ducruet, T.; Kurth, T.; Verdoux, H.; T ournier, M.; Pariente, A.; Bégaud, B. Benzodiazepine use and risk of Alzheimer's disease: case-control study. BMJ, 2014, 349, g5205.

[27] Le Fanu, J. Mass medicalization is an iatrogenic catastrophe. BMJ, 2018, 361, k2794. [28] Jones, R; Wilsdon, J. The biomedical bubble. Report, Nesta, UK. 2018. Retrieved from: https://media.nesta.org.uk/documents/The-Biomedical-Bubble.pdf [29] van Gerven, J.; Cohen, A. Vanishing clinical psychopharmacology. Br. J. Clin. Pharmacol., 2011, 72, 1-5.

[30] Baker, D.E. High drug prices: So who is to blame? Hosp. Pharm., 2017, 52(1), 5-6. [31] Brown, D.; Chow, H.; Hanna, T.M.; McDonald, D. Democratic public ownership in the UK pharmaceutical sector. 2019. Retrieved from:

https://www.globaljustice.org.uk/sites/default/files/files/resources/democratic_public_ow nership_in_uk_pharmaceutical_sector_sept_2019.pdf

[32] Mazzucato, M. The people's prescription: reimagining health innovation to deliver public value. IIPP Policy Report. Institute for Innovation and Public Purpose, University College London. 2018. Retrieved from: https://www.ucl.ac.uk/bartlett/publicpurpose/sites/public-purpose/files/peoples_prescription_report_final_online.pdf [33] The United Nations secretary-general's High-Level Panel on access to medicines release final report. 2016; Retrieved from: http://www.unsgaccessmeds.org/final-report/ [34] Caraci, F.; Leggio, G.M.; Salomone, S.; Drago, F. New drugs in psychiatry: focus on new pharmacological targets. F1000Res, 2017, 6, 397.

[35] Duman, R.S. Ketamine and rapid-acting antidepressants: a new era in the battle against depression and suicide. F1000Res, 2018, 7, 659.

[36] Leweke, F.M.; Mueller, J.K.; Lange, B.; Rohleder, C. Therapeutic potential of cannabinoids in psychosis. Biol. Psychiatry, 2016, 79(7), 604-612. 
[37] Mithoefer, M.C.; Grob, C.S.; Brewerton, T.D. Novel psychopharmacological therapies for psychiatric disorders: psilocybin and MDMA. Lancet Psychiatry, 2016, 3(5), 481-488.

[38] Sessa, B. Why psychiatry needs psychedelics and psychedelics need psychiatry. J. Psychoactive Drugs, 2014, 46(1), 57-62.

[39] Kyzar, E.J.; Nichols, C.D.; Gainetdinov, R.R.; Nichols, D.E.; Kalueff, A.V. Psychedelic drugs in biomedicine. Trends Pharmacol. Sci., 2017, 38(1), 992-1005.

[40] Sahakian, B.J.; Malloch, G.; Kennard, C. A UK strategy for mental health and wellbeing. Lancet, 2010, 375, 1854-1855.

[41] Grinspoon, L.; Bakalar, J.B. Psychedelic drugs reconsidered. Basic Books: New York, 1979.

[42] Rucker, J.j; Iliff, J.; Nutt, D.J. Psychiatry and the psychedelic drugs. Past, present \& future. Neuropharmacol., 2017, 200-208.

[43] Majic, T.; Schmidt, T .T .; Gallinat, J. Peak experiences and the afterglow phenomenon: When and how do therapeutic effects of hallucinogens depend on psychedelic experiences? J. Psychopharmacol., 2015, 29(3), 241-253.

[44] Nichols, D.E.; Johnson, M.W.; Nichols, C.D. Psychedelics as medicines: An emerging new paradigm. Clin. Pharmacol. Ther., 2017, 101(2), 209-219.

[45] Nichols, D.E. Psychedelics. Pharmacol. Rev., 2016, 68(2), 264-355.

[46] De Gregorio, D.; Posa, L.; Ochoa-Sánchez, R.; McLaughlin, R.; Maione, S.; Comai, S.; Gobbi, G. The hallucinogen d-lysergic diethylamide (LSD) decreases dopamine firing activity through 5-HT1A, D2 and TAAR1 receptors. Pharmacol. Res., 2016, 113(Pt A), 8191.

[47] Collier, T.L.; Waterhouse, R.N.; Kassiou, M. Imaging sigma receptors: applications in drug development. Curr. Pharm. Des., 2007, 13(1), 51-72.

[48] Maqueda, A.E.; Valle, M.; Addy, P.H.; Antonijoan, R.M.; Puntes, M.; Coimbra, J.; Ballester, M.R.; Garrido, M.; González, M.; Claramunt, J.; Barker, S.; Lomnicka, I.; Waguespack, M.; Johnson, M.W.; Griffiths, R.R.; Riba, J. Naltrexone but not ketanserin antagonizes the subjective, cardiovascular, and neuroendocrine effects of salvinorin- $A$ in humans. Int. J. Neuropsychopharmacol., 2016, 19(7).

[49] Catlow, B.J.; Song, S.; Paredes, D.A.; Kirstein, C.L.; Sánchez-Ramos, J. Effects of psilocybin on hippocampal neurogenesis and extinction of trace fear conditioning. Exp. Brain Res., 2013, 228(4), 481-491.

[50] Jones, K.A.; Srivastava, D.P.; Allen, J.A.; Strachan, R.T .; Roth, B.L., Penzes, P. Rapid modulation of spine morphology by the 5-HT2A serotonin receptor through kalirin-7 signaling. Proc. Natl. Acad. Sci. USA, 2009, 106(46), 19575-19580.

[51] Carhart-Harris, R.L.; Nutt, D.J. Serotonin and brain function: a tale of two receptors. J. Psychopharmacol., 2017, 31(9), 1091-1120. 
[52] Ly, C.; Greb, A.C.; Cameron, L.P.; Wong, J.M.; Barragan, E.V.; Wilson, P.C.; Burbach, K.F.; Soltanzadeh Zarandi, S.; Sood, A.; Paddy, M.R.; Duim, W.C.; Dennis, M.Y.; McAllister, A.K.; Ori-McKenney, K.M.; Gray, J.A.; Olson, D.E. Psychedelics promote structural and functional neural plasticity. Cell Rep., 2018, 23(11), 3170-3182.

[53] Kubera, M.; Maes, M.; Kenis, G.; Kim, Y.K.; Lason, W. Effects of serotonin and serotonergic agonists and antagonists on the production of tumor necrosis factor alpha and interleukin-6. Psychiatry Res., 2005, 134(3), 251-258.

[54] Yu, B.; Becnel, J.; Zerfaoui, M.; Rohatgi, R.; Boulares, A.H.; Nichols, C. D. Serotonin 5hydroxytryptamine(2A) receptor activation suppresses tumor necrosis factor-alphainduced inflammation with extraordinary potency. J. Pharmacol. Exp. Ther., 2008, 327(2), 316-323.

[55] Carhart-Harris, R.L.; Roseman, L.; Bolstridge, M.; Demetriou, L.; Pannekoek, J.N.; Wall, M.B.; Tanner, M.; Kaelen, M.; McGonigle, J.; Murphy, K.; Leech, R.; Curran, H.V.; Nutt, D.J. Psilocybin for treatment-resistant depression: fMRI-measured brain mechanisms. Sci. Rep., 2017, 7.

[56] Carhart-Harris, R.L.; Muthukumaraswamy, S.; Roseman, L.; Kaelen, M.; Droog, W.; Murphy, K.; Tagliazucchi, E.; Schenberg, E.E.; Nest, T.; Orban, C.; Leech, R.; Williams, L.T.; Williams, T.M.; Bolstridge, M.; Sessa, B.; McGonigle, J.; Sereno, M.I.; Nichols, D.; Hellyer, P.J.; Hobden, P.; Evans, J.; Singh, K.D.; Wise, R.G.; Curran, H.V.; Feilding, A.; Nutt, D.J. Neural correlates of the LSD experience revealed by multimodal neuroimaging. Proc. Natl. Acad. Sci. USA, 2016, 113(17), 4853-4858.

[57] Palhano-Fontes, F.; Andrade, K.C.; T ofoli, L.F.; Santos, A.C.; Crippa, J.A.; Hallak, J.E.C.; Ribeiro, S.; de Araujo, D.B. The psychedelic state induced by ayahuasca modulates the activity and connectivity of the default mode network. PLoS One, 2015, 10(2), e0118143. [58] Sheline, Y.I.; Price, J.L.; Yan, Z.; Mintun, M.A. Resting-state functional MRI in depression unmasks increased connectivity between networks via the dorsal nexus. Proc. Natl. Acad. Sci. USA, 2010, 107(24), 11020-11025.

[59] Holtzheimer, P.E.; Mayberg, H.S. Stuck in a rut: rethinking depression and its treatment. Trends Neurosci., 2011, 34(1), 1-9.

[60] Carhart-Harris, R.L.; Erritzoe, D.; Williams, T.; Stone, J.M.; Reed, L.J.; Colasanti, A.; Tyacke, R.J.; Leech, R.; Malizia, A.L.; Murphy, K.; Hobden, P.; Evans, J.; Feilding, A.; Wise, R.G.; Nutt, D.J. Neural correlates of the psychedelic state as determined by fMRI studies with psilocybin. Proc. Natl. Acad. Sci. USA, 2012, 109(6), 2138-2143.

[61] Schindler, E.A.D.; Wallace, R.M.; Sloshower, J.A.; D'Souza, D.C. Neuroendocrine associations underlying the persistent therapeutic effects of classic serotonergic psychedelics. Front. Pharmacol., 2018, 9, 177.

[62] MacDonald, K.; Macdonald, T.M.; Brüne, M.; Lamb, K.; Wilson, M.P.; Golshan, S.; 
Feifel, D. Oxytocin and psychotherapy: a pilot study of its physiological, behavioral and subjective effects in males with depression. Psychoneuroendocrinology, 2013, 38(12), 2831-2843.

[63] Ona, G.; Bouso, J.C. Therapeutic potential of natural psychoactive drugs for central nervous system disorders: A perspective from polypharmacology. Current Medicinal Chemistry, 2019. doi: 10.2174/0929867326666191212103330.

[64] Belser, A.M.; Ag in-Liebes, G.; Swift, T.C.; Terrana, S.; Devenot, N.; Friedman, H.L.; Guss, J.; Bossis, A.; Ross, S. Patient experiences of psilocybin-assisted psychotherapy: an interpretative phenomenological analysis. J. Humanist. Psychol., 2017, 57(4), 354-388.

[65] Liechti, M.E.; Dolder, P.C.; Schmid, Y. alterations of consciousness and mystical-type experiences after acute LSD in humans. Psychopharmacol. (Berl), 2017, 234(9-10), 14991510.

[66] Eisner, B.G.; Cohen, S. Psychotherapy with lysergic acid diethylamide. J. Nerv. Ment. Dis., $1958,127(6)$, 528-539.

[67] Garcia-Romeu, A.; Griffiths, R.R.; Johnson, M.W. Psilocybin-occasioned mystical experiences in the treatment of tobacco addiction. Curr. Drug Abuse Rev., 2014, 7(3), 157-164.

[68] Griffiths, R.R.; Richards, W.A.; McCann, U.; Jesse, R. Psilocybin can occasion mysticaltype experiences having substantial and sustained personal meaning and spiritual significance. Psychopharmacol. (Berl), 2006, 187(3), 268-283.

[69] Maclean, K.A.; Johnson, M.W.; Griffiths, R.R. Mystical experiences occasioned by the hallucinogen psilocybin lead to increases in the personality domain of openness. J. Psychopharmacol., 2011, 25(11), 1453-1461.

[70] Roseman, L.; Haijen, E.; Idialu-Ikato, K.; Kaelen, M.; Watts, R.; Carhart-Harris, R.L. Emotional breakthrough and psychedelics: Validation of the Emotional Breakthrough Inventory. J. Psychopharmacol., 2019, doi: 10.1177/0269881119855974.

[71] Bouso, J.C.; dos Santos, R.G.; Alcázar-Córcoles, M.Á.; Hallak, J.E.C. Serotonergic psychedelics and personality: A systematic review of contemporary research. Neurosci. Biobehav. Rev., 2018, 87, 118-132.

[72] Forstmann, M.; Sagioglou, C. Lifetime experience with (classic) psychedelics predicts pro-environmental behavior through an increase in nature relatedness. J.

Psychopharmacol., 2017, 31(8), 975-988.

[73] Thiessen, M.S.; Walsh, Z.; Bird, B.M.; Lafrance, A. Psychedelic use and intimate partner violence: The role of emotion regulation. J. Psychopharmacol., 2018, 32(7), 749755.

[74] Osório, F.L.; Sanches, R.F.; Macedo, L.R.; dos Santos, R.G.; Maia-de-Oliveira, J.P.; Wichert-Ana, L.; Araujo, D.B.; Riba, J.; Crippa, J.A.; Hallak, J.E. Antidepressant effects of a 
single dose of ayahuasca in patients with recurrent depression: a preliminary report. Braz. J. Psychiatry, 2015, 37(1), 13-20.

[75] Palhano-Fontes, F.; Barreto, D.; Onias, H.; Andrade, K.C.; Novaes, M.M.; Pessoa, J.A.; Mota-Rolim, S.A.; Osório, F.L.; Sanches, R.; dos Santos, R.G.; Tófoli, L.F.; de Oliveira Silveira, G.; Yonamine, M.; Riba, J; Santos, F.R.; Silva-Junior, A.A.; Alchieri, J.C.; GalvaoCoelho, N.L.; Lobao-Soares, B.; Hallak, J.E.C.; Arcoverde, E.; Maia-de-Oliveira, J.P.; Araújo, D.B. Rapid antidepressant effects of the psychedelic ayahuasca in treatment-resistant depression: a randomized placebo-controlled trial. Psychol. Med., 2019, 49(4), 655-663. [76] Sanches, R.F.; Osório, F.L.; dos Santos, R.G.; Macedo, L.R.; Maia-de-Oliveira, J.P.; Wichert-Ana, L.; de Araújo, D.B.; Riba, J.; Crippa, J.A.; Hallak, J.E.C. Antidepressant effects of a single dose of ayahuasca in patients with recurrent depression: a SPECT study. J. Clin. Psychopharmacol., 2016, 36(1), 77-81.

[77] Gasser, P.; Holstein, D.; Michel, Y.; Doblin, R.; Yazar-Klosinski, B.; Passie, T.; Brenneisen, R. Safety and efficacy of lysergic acid diethylamide-assisted psychotherapy for anxiety associated with life-threatening diseases. J. Nerv. Ment. Dis., 2014, 202(7), 513-520.

[78] Griffiths, R.R.; Johnson, M.W.; Carducci, M.A.; Umbricht, A.; Richards, W.A.; Richards, B.D.; Cosimano, M.P.; Klinedinst, M.A. Psilocybin produces substantial and sustained decreases in depression and anxiety in patients with life-threatening cancer: A randomized double-blind trial. J. Psychopharmacol., 2016, 30(12), 1181-1197.

[79] Grob, C.S.; Danforth, A.L.; Chopra, G.S.; Hagerty, M.; McKay, C.R.; Halberstadt, A.L.; Greer, G.R. Pilot study of psilocybin treatment for anxiety in patients with advanced-stage cancer. Archiv. Gen. Psychiatry, 2011, 68(1), 71-78.

[80] Ross, S.; Bossis, A.; Guss, J.; Agin-Liebes, G.; Malone, T.; Cohen, B.; Mennenga, S.E.; Belser, A.; Kalliontzi, K.; Babb, J.; Su, Z.; Corby, P.; Schmidt, B.L. Rapid and sustained symptom reduction following psilocybin treatment for anxiety and depression in patients with life-threatening cancer: a randomized controlled trial. J. Psychopharmacol., 2016, 30(12), 1165-1180.

[81] Johnson, M.W.; Garcia-Romeu, A.; Cosimano, M.P.; Griffiths, R.R. Pilot study of the 5ht2aR agonist psilocybin in the treatment of tobacco addiction. J. Psychopharmacol., 2014, 28(11), 983-992.

[82] Danforth, A.; Grob, C.S.; Struble, C.; Feduccia, A.A.; Walker, N.; Jerome, L.; YazarKlosinski, B.; Emerson, A. Reduction in social anxiety after MDMA-assisted psychotherapy with autistic adults: a randomized, double-blind, placebo-controlled pilot study. Psychopharmacol. (Berl), 2018, 235(11), 3137-3148.

[83] Bouso, J.C.; Doblin, R.; Farré, M.; Alcázar-Córcoles, M.A.; Gómez-Jarabo, G. MDMAassisted psychotherapy using low doses in a small sample of women with chronic 
posttraumatic stress disorder. J. Psychoactive Drugs, 2008, 40(3), 225-236.

[84] Mithoefer, M.C.; Wagner, M.T .; Mithoefer, A.T .; Jerome, L.; Doblin, R. The safety and

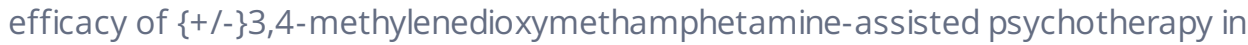
subjects with chronic, treatment-resistant posttraumatic stress disorder: the first randomized controlled pilot study. J. Psychopharmacol., 2011, 25(4), 439-452.

[85] Mithoefer, M.C.; Mithoefer, A.T .; Feduccia, A.A.; Jerome, L.; Wagner, M.; Wymer, J.; Holland, J.; Hamilton, S.; Yazar-Klosinski, B.; Emerson, A.; Doblin, R. 3,4methylenedioxymethamphetamine (MDMA)-assisted psychotherapy for post-traumatic stress disorder in military veterans, firefighters, and police officers: a randomised, double-blind, dose-response, phase 2 clinical trial. Lancet Psychiatry, 2018, 5(6), 486-497. [86] Oehen, P.; Traber, R.; Widmer, V.; Schnyder, U. A randomized, controlled pilot study of MDMA ( \pm 3,4-Methylenedioxymethamphetamine)-assisted psychotherapy for treatment of resistant, chronic Post-Traumatic Stress Disorder (PTSD). J. Psychopharmacol., 2013, 27(1), 40-52.

[87] Ot'alora, M.; Grigsby, J.; Poulter, B.; Van Derveer, J.W.; Gael, S.; Jerome, L.; Feduccia, A.A.; Hamilton, S.; Yazar-Klosinski, B.; Emerson, A.; Mithoefer, M.C.; Doblin, R. 3,4Methylenedioxymethamphetamine-assisted psychotherapy for treatment of chronic posttraumatic stress disorder: A randomized phase 2 controlled trial. J. Psychopharmacol., 2018, 32(12), 1295-1307.

[88] Bedi, G. 3,4-Methylenedioxymethamphetamine as a psychiatric treatment. JAMA Psychiatry, 2018, 75(5), 419-420.

[89] dos Santos, R.G.; Bouso, J.C.; Hallak, J.E.C. The antiaddictive effects of ibogaine: A systematic literature review of human studies. J. Psychedelic Studies, 2016, 1(1), 20-28. [90] Apud, I.; Romaní, O. Medicine, religion and ayahuasca in Catalonia. Considering ayahuasca networks from a medical anthropology perspective. Int. J. Drug Policy, 2017, 39, 28-36.

[91] Langdon, E.J. The revitalization of yajé shamanism among the siona: strategies of survival in historical context. Anthropology of Consciousness, 2016, 27(2), 180-203. [92] Wiedman, D. Big and little moon peyotism as health care delivery systems. Med. Anthropol., 1990, 12(4), 371-387.

[93] Góngora, J.N. Reflexiones sobre la crisis en Haití: del individuo a la comunidad. Cuadernos de Psiquiatría Comunitaria, 2010, 1, 9-27.

[94] Scholte, W.F.; Verduin, F.; Kamperman, A.M.; Rutayisire, T.; Zwinderman, A.H.; Stronks, K. The effect on mental health of a large scale psychosocial intervention for survivors of mass violence: A quasi-experimental study in Rwanda. PLoS One, 2011, 6, e21819.

[95] Verduin, F.; Smid, G.E.; Wind, T.R.; Scholte, W.F. In search of links between social 
capital, mental health and sociotherapy: A longitudinal study in Rwanda. Soc. Sci. Med., 2014, 121, 1-9.

[96] Trope, A.; Anderson, B.T.; Hooker, A.R.; Glick, G.; Stauffer, C.; Woolley, J.D. Psychedelic-assisted group therapy: A systematic review. J. Psychoactive Drugs, 2019, 51(2), 174-188.

[97] Wang, J.; Mann, F.; Lloyd-Evans, B.; Ma, R.; Johnson, S. Associations between loneliness and perceived social support and outcomes of mental health problems: a systematic review. BMC Psychiatry, 2018, 18(1), 156.

[98] Holt-Lunstad, J.; Smith, T.B.; Baker, M.; Harris, T.; Stephenson, D. Loneliness and social isolation as risk factors for mortality: a meta-analytic review. Perspect. Psychol. Sci., 2015, 10(2), 227-237.

[99] Goldsmith, N.M. Psychedelic healing: The promise of entheogens for psychotherapy and spiritual development. Inner T raditions \& Bear: Rochester, 2010.

[100] Johansen, P.O.; Krebs, T.S. Psychedelics not linked to mental health problems or suicidal behavior: A population study. J. Psychopharmacol., 2015, 29(3), 270-279. [101] Hendricks, P.S.; Thorne, C.B.; Clark, C.B.; Coombs, D.W.; Johnson, M.W. Classic psychedelic use is associated with reduced psychological distress and suicidality in the United States adult population. J. Psychopharmacol., 2015, 29(3), 280-288.

[102] Ona, G.; Kohek, M.; Massaguer, T.; Gomariz, A.; Jiménez D.F.; dos Santos, R.G.; Hallak, J.E.C.; Alcázar-Córcoles, M.Á.; Bouso, J.C. Ayahuasca and public health: Health status, psychosocial well-being, lifestyle, and coping strategies in a large sample of ritual ayahuasca users. J. Psychoactive Drugs, 2019, 51(2), 135-145.

[103] dos Santos, R.G.; Bouso, J.C.; Hallak, J.E.C. Ayahuasca, dimethyltryptamine, and psychosis: a systematic review of human studies. Ther. Adv. Psychopharmacol., 2017, 7(4), 141-157.

[104] Johnson, M.W.; Richards, W.; Griffiths, R.R. Human hallucinogen research: guidelines for safety. J. Psychopharmacol., 2008, 22(6), 603-620. 